\title{
OBITUARY
}

\section{WALTER BAUER, 1898-1963}

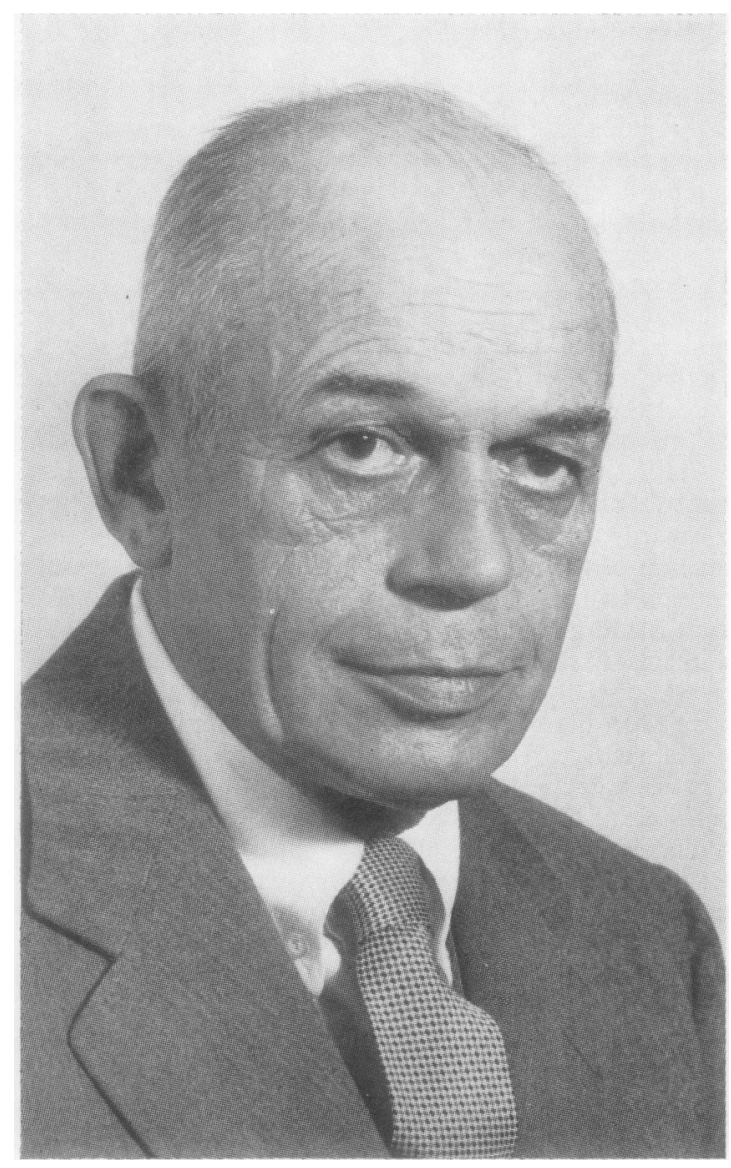

Walter Bauer, who died on December 2 aged 65, in the course of a chronic respiratory disease which had limited his forceful abilities for some time, was the most important of all figures in the development of rheumatology as an integral part of general medicine and in its emergence from the disrepute and neglect into which it had fallen since the time of Garrod. Yet it was not until 1929 that his interest turned in this direction from the careful metabolic studies of bone disease which hitherto had occupied his attention. In that year he took on the direction of the Lovett Memorial Fund for the study of crippling diseases in the Massachusetts General Hospital, where he had first come as a resident 6 years before, after graduation at Michigan (the State of his birth) in 1922. He spent a year with Sir Henry Dale in London (1927-28) and then returned to Harvard and the Massachusetts General Hospital, with which his name has become indissolubly linked. The Massachusetts General Hospital when I first knew it in 1937 was the Mecca of every young aspirant to Medicine. Walter Bauer and Fuller Albright, then at the height of his great achievements, Howard Means* on the thyroid, John Talbott on gout, Paul White and Ed. Bland in cardiology, Rackemann Chester Jones, and others too numerous to mention, made this a unique centre, rivalled only by the Thorndike Laboratory at the Boston City Hospital with Castle and his talented colleagues, Chester Keefer, Max Finland, etc. For those interested in rheumatology there was the added attraction of orthopaedic rounds (alas, at 8.00 a.m. on a Monday morning!) with such giants as SmithPetersen and Joe Barr. Walter Bauer symbolized the heights to which the practice and study of medicine could rise: dynamic and forceful, zestful, energetic and boyishly enthusiastic, he could yet be crushingly critical. He started work on rheumatism from the grass roots up, with physiological studies on synovial fluid and cartilage in cattle and dogs (1930-32) and with pathological and experimental work in association with Red Bennett at the Harvard Medical School. He initiated long-term studies of the onset and course of rheumatoid arthritis compared statistically with an equal number of carefully selected controls, in which he was ably assisted by his associates, Marian Ropes, now President of the A.R.A., and Charley Short, an ex-President, as well as by a host of others too numerous to mention. He inspired loyalty, devotion, and affection, as well as chronic overwork, but he drove himself even harder than he did his colleagues. His Unit was a meeting place for people from all over the world; at Arthritis Rounds on Mondays in the Ether Dome, you would see, besides the Egyptian Mummy and the Greek statuary, Englishmen and Scotsmen, Canadians, Australians, Mexicans, SouthAmericans, Europeans, and of course the cream of the United States. His pupils are now in key positions all over the U.S.A. and elsewhere as well; a fantastic number

* He has written delightfully on the developments of this period in 
and for the most part actively engaged in advancing the frontiers of our knowledge.

During the war, Walter Bauer initiated and took on a major commitment in developing postgraduate medical education in army hospitals, making these, often in other countries stagnant pools of routine duties, places and instruments of progress. I visited Harvard many times after the war, during the rapid expansion that took place in that decade: the major change that Walter Bauer put into operation was the development of a basic Sciences section, at first in association with Jerry Gross at M.I.T. and then in new buildings within the curtilage of the hospital. By themselves or in close association with their clinical colleagues, fundamental advances in our knowledge of connective tissue in health and disease came from the Lovett Group, in more recent years including immunology, enzymology, bacteriology, and polysaccharide chemistry-a general account of which Walter Bauer gave in his Heberden Oration for 1955 (delayed by pressure of work until 1956 $\dagger$ and reported in the Annals for 1957 as publication No. 202 of the Robert W. Lovett Memorial Foundation for the Study of Crippling Diseases). This gives well the flavour of Walter Bauer's characteristically practical and yet philosophic approach to

$\dagger$ Walter Bauer (1956). "Research and the Rheumatic Diseases", Ann. rheum. Dis., 16, 1. research, care, and teaching, in each of which he was pre-eminent. When Howard Means retired in 1951, Walter Bauer became Jackson Professor of Clinical Medicine in the University, with very heavy responsibilities which left him much less time with the Rheumatism Group than before. He remained a guiding influence, however, not only there but with many American and international scientific societies, and with such important bodies as the Arthritis and Rheumatism Foundation, the Helen Hay Whitney Foundation, the National Foundation, and the Wellcome Fund. Such a burden of duties and such singlemindedness in fulfilling them meant heavy demands on his personal life: he was blessed with a charming and understanding wife, with whose help he was enabled not only to fulfil himself so uniquely in his chosen field but also to raise a happy family of three children and to enjoy a pleasant and intellectual home atmosphere: first in Waban and latterly in Cambridge; their hospitality has been enjoyed by many, young and old, from all over the world.

Walter Bauer gave himself fully to his pupils, to Harvard and the Massachusetts General Hospital, and to the world; his spirit lives on, not only in his family and in the work he did, but in the institutions he moulded and in the many people throughout the world who have been inspired by his example.

E.G.L.B.
During the last year we have lost three Englishmen who in their spheres have contributed a great deal to British rheumatology.

LORD EVANS, so human and such a friend to all he met that he was known to all as Horace, was for many years a member of the Heberden Society. In spite of his many commitments in caring for the royal family and so many important personages, his committee work, and his duties at the London Hospital, he was a regular attender at clinical meetings in rheumatology and always ready to vouch for its importance as an integral part of clinical medicine.

Derrick Coltart, the Barts orthopaedist, was not only a member of the Heberden Society, but for some years Chairman of the Education Committee of the Empire Rheumatism Council. He was on the staff of the Arthur Stanley Institute and did much to improve the orthopaedic treatment of the rheumatic diseases.

Dr. Arthur Willcox of the Middlesex Hospital was again a very loyal supporter of the Heberden Society and served on the Scientific Advisory Committee of the Empire Rheumatism Council. While working in general medicine, rheumatology was one of his major interests, and he spared no pains to assist in organizing meetings and was a regular attender at such meetings abroad as well as at home.

These three, all working in rather different fields, brought together only perhaps by their appreciation of the importance of the better treatment of the rheumatic sufferer, were all great and very likeable men, whom we shall all miss as friends and colleagues and shall find difficult to replace.

G.D.K.

\section{CORRECTION}

In an abstract of a paper by Dr. Irwin Oreskes entitled "Reactivity of Rheumatoid Arthritis Sera with Altered and Aggregated Human $\gamma$ Globulin", $\beta$ was wrongly substituted for $\gamma$ in the title (see Annals, 1963, 22, 381). 